\title{
THE ACTIVITIES OF THE POLISH CATHOLIC CARITAS IN GREAT BRITAIN, ITALY AND DENMARK 1956-1962
}

\section{INTRODUCTION}

In 1945, Fr. Rafał Gogoliński-Elston made contact between the Archbishop of Kraków, Adam Stefan Sapieha, and the National Catholic Welfare Conference (NCWC) in order to provide charity assistance by the NCWC to Poles in the country, though Caritas in Poland. ${ }^{1}$

In 1946-1948, medicine, clothing, food for \$ 80,000 was sent to Poland from the NCWC warehouses in Great Britain. Six trucks for Caritas were sent to Poland, children's homes were sent blankets, bed linen, kitchen appliances, stationary such as paper, pencils, ink and typewriters. In 1950-1951, 80 boxes containing medicine and medical equipment worth over $\$ 10,000$ were sent to Poland.

In 1952 Fr. Rafał Gogoliński-Elston founded the Polish Catholic Caritas Branch in Great Britain. Polish Caritas in Great Britain in the years 1952-1957, sent to Poland: 4000 food parceles, CARE for a total amount of $\$ 40,000 ; 6,000$ food packages, from the US Department of Agriculture, worth \$30,000. In the years 1950-1960, Polish Caritas sent Christmas parcels for Polish priests who where in difficult financial conditions. Every year, over 100 parcels were sent during Christmas for a total of over $\$ 4,000$. Caritas helped children and youth in Polish Catholic schools in Great Britain. Granted scholarship to students. In financed 106 summer camps for 2,650 children.

In November 1956, Fr. Rafał Gogoliński-Elston founded branches of the Polish Catholic Caritas in Denmark and Sweden, having obtained funds for these Departments Denmark received finances for: 2 Polish schools for Polish children; 3 Polish

Fr. Dr. Roman NiR - Institute of History and Polonia Archives. Former Director of the Central Polonia Archives at Orchard Lake, USA. Historian and Polonia Archivist. Ordinary member of the PTNO; e-mail: romannir@gmail.com.

${ }^{1}$ Archives of Rev. Msgr Alexander Gogoliński-Elston, War Relief Services-NCWC, Polish Projects in Great Britain, London, pp. 51, [hereafter: AGOG]. 
community centers; 6 mobile Polish libraries; for youth theaters and the activity of a Polish priest $(\$ 4,780)$.

Sweden has received funding for: 11 Polish Saturday schools, 6 mobile Polish libraries, and 1 youth club $(\$ 3,890){ }^{2}$

Rev. Msgr. Aleksander Rafał Gogoliński-Elston, JCD, held a number of responsible functions in the United Kingdom. He was an National Catholic Welfare Conference delegate for Polish affairs in Great Britain, from December 1943 to January 1946; a NCWC delegate for refugees of 18 nationalities from January 1946 to January 1949; Director of the NCWC in 1949-1954; and director of the NCWC Mission for the United Kingdom from 1954.

He was the director the Polish Catholic Caritas in Great Britain, Italy and Denmark 1946-1965. He was a co-founder of the Association of Polish Priests in Great Britain, and he served as a treasurer and secretary. He issued pastoral aids for priests. He was the vice president of the Polish Air Force Association in Great Britain, Chief Chaplain of the Polish Scouting Association. On Radio BBC Polish Section 1 he delivered homilies on Sundays. He was awarded numerous military and church decorations. ${ }^{3}$

\section{POLISH SCHOOLS IN GREAT BRITAIN - 1957}

In Great Britain there are three Boarding Schools for Polish children and youth: one for girls at Pitsford Hall (Northants) and two for boys: at Hereford and at Fawley Court (Oxon).

These schools are fully licensed and are equal in every respect to the English ones. All subjects are taught in English and the Polish boys and girls have considerable difficulty in learning the history of their nation, and even opportunities of learning their mother tongue are not sufficient. The governing bodies of these schools have the best intentions in this respect but the schools are not able even teach their pupils Polish national songs and folk dances for lack of competent teachers.

For the education of these Polish youth in their national spirit, for awakening of their national pride, to foster in them a consciousness of Polish traditions it is neces-

2 The author of the monograph, Rev. Dominik Zamiatala CMF, Caritas. Działalność i likwidacja organizacji 1945-1950, Lublin 2000, did not reach the archives of the London Rev. Msgr Gogoliński-Elston. Therefore, in the monograph we do not find information about the actovities of Polish Caritas in Great Britain, Italy and Denmark. There is no information in the monograph about NCWC's help for Caritas in Poland.

3 Archives Rev. Msgr Roman Nir, Rev. Msgr Alexander Gogoliński-Elston JCD (1902-1982), pp. 1-10 [hereafter: ARN]. 
sary to engage a special teacher of the Polish language, history and national customs at each of these schools. Because of the number of pupils a teacher would have a full time job in each of these schools having classes for all groups on all weekdays.

If the schools were able to form Polish choirs, national dance ensembles and dramatic circles, it would then be possible for them to take part in Polish national celebrations and gatherings. This would give more life to the gatherings organized by Poles in various parts and localities of Great Britain and make them more enjoyable.

Youth brought up in the Polish national spirit, with knowledge of Polish history, adherent to Polish traditions and national customs will be the best cultural asset for the Polish community in Great Britain and would simultaneously become the best antidote against the schemes of the communist Polish consulates. The influence of these young people would not be confined to their families only but would radiate throughout the whole Polish community in Great Britain.

\section{ESTIMATES}

(a) TEACHER:

In each of the above mentioned schools must be at least one teacher working 7 days (45-50 hours) per week (full time job).

The teacher's salary would amount in the boys schools to $£ 40$ (\$112.00) per month, and in the girls' school (where there are 170 Polish girls and where it is necessary to have 2 teachers but working 35 hours per week): per month $£ 50$ (\$140);

(b) CHILDREN'S LIBRARY:

To start a Children's Library in each school it will be necessary to purchase at least 80-100 Polish books, which would cost about $£ 35$ (\$100.00). ${ }^{4}$

\section{ESTIMATED EXPENDITURE IN SCHOOLS}

(1) PITSFORD HALL near Northampton: (170 Polish girls):

Primary School (girls aged: 6-11 y.).

Secondary and Grammar Schools: (girls aged: 11-17 y.).

Per Month For 6 months' period: January - June, 1957

(a) Teacher (s)

(b) Children's Polish Library

$$
\begin{array}{lrr}
£ 50(\$ 140.00) & £ 300 & \$ 840.00 \\
& £ 335 & \frac{100.00}{\$ 940.00}
\end{array}
$$

Total:

${ }^{4}$ Archives of War Relief Services/National Catholic Welfare Conference, Baltimore, Maryland, Special Collections, Aloysius J. Wycislo Papers (1943-1967) [hereafter: AAW], sign. 101, pp. 4-5; AGOG, sign. 511, Polish Schools in Great Britain - 1957, pp. 1-2. 
(2) HEREFORD: Primary School for 90 Polish boys (aged 6-12 y.):

Per Month For 6 months' period:

January - June, 1957

(a) Teacher

$£ 40 \$ 120.00)$

$£ 240 \quad \$ 672.00$

(b) Children's Library

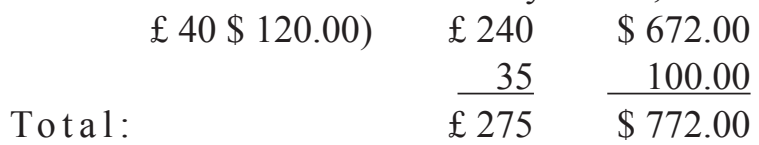

(3) FAWLEY COURT (near Henley-on-Thames, Oxon) Grammar School for 80 Polish boys (aged 11-18 y.):

6 months' period:

(a) Teacher

(b) per month: $£ 40 \$ 112.00$

$£ 240 \quad \$ 672.00$

Children's Library

$\frac{35}{£ 275} \frac{100.00}{\$ 772.00}$

TOTAL EXPENDITURE FOR 3 SCHOOLS (ESTIMATE) - 6 Months' period:

(1) PITTSFORD HALL (Schools for 170 Polish girls) $£ 335 \quad \$ 940.00$

(2) HEREFORD (School for 90 Polish boys)

$275 \quad 772.00$

(3) FAWLEY COURT (School for 80 Polish boys)

Total:

$\frac{275}{£ 885} \$ \frac{772.00}{\$ 2,484.00}$

Polish Caritas in Great Britain will be responsible for the administration of funds designed for the payment of teachers and for the Children's Libraries. It will also be responsible for submitting of financial reports in accordance with instructions which may be received in this matter.

Bearing in mind the fact that deprived of instruction in their own language Polish children and Polish youth are very quickly lost to the Polish community and they lose the feeling of belonging to a nation whose traditions are worthy to be continued, we submit our request that the sum of $\$ 2,484.00$ ( $£ 885$ ) will be generously granted to us by the Free Europe Citizens' Service for the above mentioned purposes. ${ }^{5}$

SUMMER CAMPS FOR POLISH CHILDREN AND YOUTH IN GREAT BRITAIN - 1957

CHILDREN (T-12 y. old)

BOYS

$\begin{array}{cccc}\text { Locality } & \text { Period } & \text { Remarks } & \text { Number } \\ \text { 1. CANVEY ISLAND } & \text { 16.8.-31.8. } & & 40\end{array}$

Stella Maris Essex

${ }_{5}^{5}$ AGOG, sign. 511, Pittsford, Hereford, Fawley Court, pp. 3-4; AAW, sign. 101, pp. 1; Archives Catholic University of America. Department of Archives, Manuscript and Museum Collections: National Catholic Welfare Conference/United States Catholic Conference Collection Descript. General Description Records 1919-1995, sign. 501, [hereafter: ACUA]. 
2. DELAMERE PARK

17.7.-11.8.

"Cubs"

163

Cheshire

Boy Scouts

3. DELAMERE Park

12.8.-30.8. "Cubs" \& others

185

Cheshire

4. LILFORD PARK

28.7.-17.8.

196

nr. Peterborough

5. KELVEDON

3.8. -17.8 .

208

Essex

6. PENRHOS

3.8.-17.8.

46

N. Wales

7. WOODSIDE HOUSE

3.8.-17.8.

76

St. Briavels, Gols.

8. GLENGONNAR CAMP 27.7.-11.8.

62

Scotland.

Total Boys:

976

GIRLS

\begin{tabular}{|c|c|c|c|}
\hline 9.(1) & $\begin{array}{l}\text { CANVEY ISLAND } \\
\text { Essex }\end{array}$ & 1.8.-14.8 & $\begin{array}{l}\text { "Brownies" } \\
\text { Girl Guides } \\
\text { And others }\end{array}$ \\
\hline $10 .(2)$ & $\begin{array}{l}\text { COOKHAM } \\
\text { Bucks. }\end{array}$ & $27.7 .-11.8$ & " \\
\hline 11.(3) & $\begin{array}{l}\text { DELAMERE PARK } \\
\text { Cheshire }\end{array}$ & $27.7 .-11.8$ & $"$ \\
\hline 12.(4) & $\begin{array}{l}\text { LILFORD PARK } \\
\text { nr. Peterborough }\end{array}$ & 27.7.-11.8. & $"$ \\
\hline 13.(5) & $\begin{array}{l}\text { WEETING HALL } \\
\text { Norfolk }\end{array}$ & 26.7.-14.8. & ” \\
\hline 14.(6) & $\begin{array}{l}\text { GLENGONNAR CAMP } \\
\text { Scotland }\end{array}$ & 12.8.-24.8. & ” \\
\hline
\end{tabular}

Total Girls:

313

Children: Boys and Girls: Total: 1,289

YOUTH (12-17 y. old)

Locality

Period Remarks Number BOYS

1. ABERSWYTH

3.8.-17.8.

Boy Scouts

45

Cardiganshire

3.8.-17.8.

and others

2. COMBE FARM

Sussex 
3. DELAMERE PARK 28.7.-11.8 $\quad$ 44

Cheshire

4. SUTTON COLDFIELD 27.7.-17.8. " $\quad 176$

nr. Birmingham

5. SUTTON PARK 1.8.-14.8. "

nr. Birmingham

6. HEREFORD 26.7.-24.8. Mobile Camp 41

Boys Total:

458

GIRLS

7.(1) COOKHAM

Bucks.

27.7.-11.8. Girl Guides

82

and others

8.(2) PUTSFORD

1.8.-21.8

80

Northants.

9.(3) VENTOR

17.8.-31.8

42

Isle of Wight

10.(4) WINDSOR

27.7. -11.8 .

26.8. -10.9 .

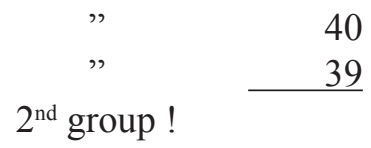

Girls Total: $\quad 283$

YOUTH: Boys and Girls: Total: $\quad 741^{6}$

SENIOR BOYS AND SENIOR GIRLS (17-22 y. old)

BOYS and GIRLS

Boys Girls Total

1. INLAND WATERS SAILING

27.-10.8. 12 yachts $\quad 79 \quad 56 \quad 135$

On Norfolk Broads

2. DEEP SEA YACHTING

27.7.-10.8. 4 yachts $22 \quad 10 \quad 32$

From Portsmouth through the

English Channel

3. DEEP SEA YACHTING

24.8.-7.9. 2 yachts $15 \quad 6 \quad 35$

$2^{\text {nd }}$ group

4. MOUNTAINEERING EXPEDITIONS 20.7.-10.8.

(Cumberland District and Wales)

\begin{tabular}{lrrr} 
& 20 & 15 & 35 \\
\cline { 2 - 3 } Total: & 136 & 87 & 223
\end{tabular}

The participations in the Inland Waters Sailing and Deep Sea Yachting came from various countries (Europe, Canada, and even so far afield as Nairobi, Kenia, East Africa).

${ }^{6}$ AGOG, sign. 512, Summer Camps for Polish Children, pp. 1-3; AAW, sign. 102, pp. 2; ARN, Msgr Gogoliński, pp. 12-13. 


\section{Groups Camps Numbers}

Children

(7-12 y.)

Youth

$\begin{array}{llllll}\text { Boys } & 8 & 7 & 976 & & \\ \text { Girls } & 6 & 6 & 313 & \text { Children Total: } & 1289\end{array}$
(12-17 y.)

\begin{tabular}{rrrrrr} 
Boys & 6 & 6 & 458 & & \\
Girls & 5 & 4 & 283 & Youth Total: & 741 \\
\cline { 2 - 3 } Total: & 25 & 23 & & & 2030
\end{tabular}

Senior Youth (17-22 y.)

\begin{tabular}{rrrrr} 
Boys & 4 & 136 & & \\
Girls & & \multicolumn{87}{c}{ Seniors Total: } & 223 \\
\cline { 2 - 3 } GRAND TOTAL: & Groups: 29 Camps 23 & & Children and Youth: & 2253
\end{tabular}

Boys: $\quad 1570$

Girls: $\quad 683$

Total: $\quad 2253^{7}$

\section{EXPENSES}

Personal expenses

1. Improvement of alimentation

$\$ 1,602.60$

Payment of Instructors' out-of-

pocket expenses

118.00

Subsidies for children and youth

who could not afford to pay full

charges (611 pers.)

$1,750.30$

Payments for these who could

not pay at all: (117 children)

803.10

$\$ 4,274.00$

2. Equipment

Equipment: 19 large tents

$\$ 1,454.95$

334 double blankets

$1,129.95$

12 groundsheets

91.98 
mattresses, etc. $\quad 206.39$

Sports Equipment:

others

476.28

$3,730.00$

Books

110.00

Prizes for Sport and other competitions:

$136.00 \quad 3,976.00$

Expenses: Total:

$\$ 8,250.00$

I hereby certify that the expanses above mentioned were covered by Polish Caritas Abroad from the grant of $\$ 8,250.00$ (eight thousand and two hundred fifty dollars, 0/00) made by Free Europe Citizens' Service of the Free Europe committee, Inc., the whole amount of which has been expended as stated above.

The places chosen for the summer camps were situated in hilly afforested localities on the banks of rivers or lakes.

The individual camps accommodated from 30 to 208 children or young people. Each camp lasted 14-16 days.

Some of the camps took two successive groups of young people.

The equipment purchased out of the subsidy from Free Europe Citizens' Service (19 tents, 300 blankets and sports equipment, etc.) not only made it possible for greater numbers of children and young people to profit from the camps but also enabled them to live in the conditions they most liked, i.e. so as to be able to pitch tent in different places at will.

Children of mixed marriages (Anglo-Polish and Scots-Polish) attended the camps ( 98 boys and 112 girls: Total 210).

The camps were also attended by children ( 57 boys and 49 girls - Total: 106) who came to Great Britain from Poland with their parents on visits of a few months duration to relatives or their families.

The children and young people were sorted into groups in accordance with their age and knowledge of the Polish language. Those who could not speak Polish at all learnt sufficient basic Polish words in the camps for it to be possible before the camps ended to make one's self understood with them in Polish.

Polish language and Polish history lessons were held daily. There were talks on Poland every evening.

\section{EXPENSES}

Polish Caritas Abroad received a subsidy of $\$ 8,250.00$ for this purpose from Free Europe Citizens' Service.

Polish Caritas Abroad was also responsible for the allocation and administration of this money. 
The above mentioned sum was fully expended in accorance with the attached list of expenses (Enclosure "B").

A great amount of equipment such as, for example 19 large tents, 300 double blankets, groundsheets, pots, beds, etc., was purchased out of this subsidy, and has been carefully stored. It will serve the Polish young people and children in the summers of 1958 and future years.

The same applies to the sports equipment (10 volleyball nets, volleyballs, footballs etc.).

\section{ACHIEVEMENTS}

The results achieved exceeded all expectations. The children and the young people lived in a truly Polish atmosphere during the whole time. The children of the mixed Polish-British marriages were in this atmosphere for the first time in their lives. It was a crucial turning in their lives. ${ }^{7}$

\section{REPORT:}

Summer Camps for Polish Children and Youth in Gt. Britain 1957

Thanks to the great help of the Free Europe Citizens' Service of the Free Europe Committee, Inc., summer camps were organized for Polish youth and children in Great Britain during the period July - August, 1957.

The attached list " $A$ " shows the places at which these camps were situated, the time for which the young people stayed there and the number of boys and girls who profited from the camps.

As can be seen from the list, there were 25 camps altogether:

(a) For children: $\quad$ Boys: $\quad 8$ camps (in all 976 boys)

Girls: $\quad 6$ camps (in all $3 \underline{13 \text { girls) }}$ Total: 1,289

(b) For teenagers (12-18 years old):

Boys: $\quad 6$ camps (in all 458 boys)

Girls: $\quad 5$ camps (in all 283 girls) Total: 741

Grand total: $\quad$ Boys: 14 camps (in all 1434 boys)

Girls: $\quad 11$ camps (in all 596 girls) Total: 2,030

In addition to the fixed camps, mobile camps were organized for older youth (17-25 years of age).

${ }^{7}$ AGOG, sign. 314, Expenses, Achievements, Free Europe Citizens's Service of the Free Europee Committee, Inc., pp. 4-8; AAW, sign. 104, pp. 1-2; ACUA, sign. 501. 
These were:

(1) inland waters sailing on Norfolk Broads (12 yachts)

135 b. \& g's

(2) deep Sea Yachting

32

(3) mountaineering Expeditions (Cumberland District)

35

(4) deep sea yachting (2nd group)

A total of 136 boys and 87 girls took part in these adventures.

The places chosen for the Summer Camps were situated in hilly afforested localities on the banks of rivers or lakes.

The individual camps accommodated from 30 to 208 children or young people. Each camp lasted 14-21 days.

Some of the camps took two successive groups of young people.

The equipment purchases out of the subsidy from Free Europe Citizen's Service (e.g. 19 tents, 334 blankets, groundsheets, sheets etc. and sports equipment) not only made possible for greater numbers of children and young people to profit from camps but also enabled them to live in the conditions they most liked, i.e. so as to be able to pitch tent in different places at will.

Children of mixed marriages (Anglo-Polish and Scots-Polish) attended the camps (98 boys and 112 girls - total: 210).

The summer camps were also attended by children ( 37 boys and 29 girls - total: 66) who came to Great Britain from Poland with their parents on visits of a few months duration to relatives or their families.

The children and young people were sorted into groups in accordance with their age and knowledge of the Polish language. Those who could not speak Polish at all learnt sufficient basic Polish words in the camps for it to be possible before the camps ended to make one's self understood with them in Polish.

Polish language and Polish history lessons were held daily. There were talks on Poland every evening. ${ }^{8}$

\section{EXPENSES}

Polish Caritas Abroad received a subsidy of $\$ 8,250$ for this purpose from Free Europe Citizens' Service.

Polish Caritas Abroad was also responsible for the allocation and administration of this money.

The above mentioned sum was fully expended in accordance with attached list of expenses. (Enclosure "B").

${ }^{8}$ AGOG, sign. 315, Report Summer Camps for Polish Children and Youth in Gt. Britain - 1957, pp. 1-5; AAW, sign. 105, pp. 1-2. 
A great amount of equipment such as, for example 19 large tents, 334 blankets (double), groundsheets, sheets, pots, beds etc., was purchased out of this subsidy, and has been carefully stored. It will serve the Polish young people and children in the summers of 1958 and future years.

The same applies to the sports equipment (volleyballs, volleyballs, double top tennis nets, etc.).

\section{ACHIEVEMENTS}

The results achieved exceeded all expectations. The children and the young people lived in a truly Polish atmosphere during the whole time. The children of the mixed Polis - British marriages were in this atmosphere for the first time in their lives. It was a crucial turning in their lives.

The subsidy helped to cover the costs of attendance of Hungarian young people ( 31 boys) at the Scouts Jamboree and at the camps. Likewise young Polish people (40 boys and 30 girls) who came from France were able to attend the camps thanks to the subsidy. ${ }^{9}$

\section{CHILDREN FROM POLAND}

A great and unanticipated experience was the sojourn in our Summer Camps in 1957 of 66 children from Poland (37 boys and 29 girls) who had come to Great Britain to spend the holidays with their relatives.

It was not possible to create a special group for these children, nor to place them all in one camp. However it transpired that the allocation of these children in small groups to various camps gave exceedingly good results.

The experience of the free Polish atmosphere was a revelation to them. The sojourn in the Camps of these children from Poland, reared in so different an atmosphere in their own country, has no doubt made an enduring impression upon them.

As is shown by letters from the parents and also from press reports the results of the Summer Camps in 1957 were excellent.

The fact that the Camps did achieve such great results is due above all to the generous help granted to the Polish children and Polish young people by Free Europe Citizens' Service of the Free Europe Committee, Inc., for which we offer here our profoundest and heartiest thanks.

Long experience has led Caritas in Great Britain to the conviction that the best means of arousing and maintaining the national spirit and sentiment in Polish children and youth is a sojourn in Polish Summer Camps organized fro them.

The Polish children and youth residing in Great Britain and attending English schools, or even boarding at public schools (i.e. private schools) forget their mother

\footnotetext{
9 AGOG, sign. 316, Polish Caritas Abroad, pp. 1-2; AAW, sign. 106, pp. 1-2; ACUA, sign. 501.
} 
tongue, and often cannot speak it or understand it at all. They do not know their country's history or its traditions.

When they are in such Summer Camps they are in a completely Polish milieu. Courses in the Polish language, literature and Polish history, are organized in all these camps. The children and young people attending the camps also have every opportunity for learning Polish songs and dances.

One of the most important tasks of the Polish Summer Camps is to select suitable individuals from among older of the young Polish people, and train them to become leaders and instructors in the future to teach the rising Polish generation love for and the traditions, customs and language of their fatherland.

The leaders of the Camps are experienced instructors and teachers, whose work is entirely voluntary (travel and other essential out - of - pocket expenses will be reimbursed). They are nearly all members of the Polish Scouting and Guides Movement.

The Regulations lay down a strict daily program, so that the time spent in the Camps is fully exploited for the achivement of these aims and objects.

Experience to date shows that the results in the fostering the national spirit in the Polish children and young people who attend these Camps are quire unexpectedly excellent.

During the summer of 1958 the intention is to organize greater number of Summer Camps.

The period to be spent in the Camps is a fortnight for each group. (In Delamere Park and Canvey Island: for two successive groups).

As the Polish community in this country is, generally speaking, poor, the charges for a sojourn in the Camps are low - barely sufficient to cover the minimum costs of maintainance. Even so, many of the parents cannot afford this small charge. So many of the children and young people are quite unable to take even so cheap and profitable a holiday.

The fare provided in the Camps, though healthy, is of necessity barely sufficient for growing boys and girls. There is a chronic lack of the most indispensible equipment such as sports gear for indoor and outdoor games, elementary gymnastic equipment, study books and reading libraries.

Small funds are also required and desirable for the provision of prizes for sports and other competitions.

(Especial importance is attached to the yachting and mountaineering groups because they attract youth Polish people aged between 17 and 25 from distant parts to which they return strengthened spiritually in the Polish tradition).

A list of the Camps with particulars as to locality, number of participants and their ages is attached.

An estimate of the minimum help required is also attached. 
In view of the great significance of the aims of this work in the camps we earnestly ask the Free Europe Citizens' Services to help us by granting \$ 8,250.00 for the purpose of these Summer Camps.

Polish Caritas in Great Britain will make it self responsible for the administration of any subsidy granted and will send detailed accounts of expenditure together with the relevent supporting vouchers.

Narrative reports will also be prepared and despatched with accompanying photographs etc. in due course. ${ }^{10}$

\section{REPORT: POLISH SCHOOLS IN ENGLAND}

There are 3 Boarding Schools for Polish children and youth in Great Britain:

(a) 1 for girls: at Pitsford Hall (Northants).

(b) 2 for boys:

(1) at Hereford

(2) at Fawley Court, Henley-on-Thames, Oxon.

These schools are fully licensed and are equal in every respected to the English ones. All subjects are taught in English and the Polish boys and girls used to have considerable difficulty in learning the history and geography of their nation, and even lacked opportunities of learning their mother tongue.

Quite simply, the Governing Bodies of these schools had not sufficient funds to carry out their intentions in this respect and could not engage personnel competent to teach their pupils these subjects and the complementary Polish national songs and dances.

The grants to the sum of $\$ 940.00$ for school at Pittsford, and of $\$ 772.00$ for each of 2 schools for boys (Hereford and Fawley Court) not only made it possible to have these subjects taught at last, but also led in these schools to the creation of Polish choirs, national dance ensembles, dramatic circles and also of active sports clubs.

All this raised the Polish national spirit considerably not only among the pupils at these schools, but also among their families and general adult circles.

The pupils appeared at many Polish gatherings singing Polish songs and dancing Polish folk dances in their regional costumes.

The sports clubs competed very succesfully with teams from English schools, which was all a great encouragement to the national pride of the pupils and of the Polish community in general.

The generous grants of the Free Europe Citizens' Service made to these 3 schools have been of very considerable benefit, and have served as an antidote to the loss of Polish national spirit among the pupils and even the adult Polish emigres, and to the persistent machinations of the Polish communist agents.

\footnotetext{
${ }^{10}$ AGOG, sign. 317, Children from Poland, pp. 1-5; AAW, sign. 107, pp. 1.
} 
Three separate financial reports are attached in respect of the grants made to each of the schools at Pittsford, Hereford and Fawley Court.

The Polish Caritas in Great Britain thanks the Free Europe Citizens' Service of the Free Europe Committee, Inc., most profoundly for their generous and splendid help, the results of which can be seen on a very small scale in the enclosed photographs. These results would all have been quite impossible without the generous help and support granted by the Free Europe Citizen's Service. ${ }^{11}$

\section{SCHOOL FOR POLISH GIRLS: PITSFORD HALL (NORTHANTS) ENGLAND}

Period: January - June, 1957

Girls: 175

(a) Primary School - girls aged: 6-11.

(b) Secondary and Grammar Schools - girls aged: 11-17.

Lesson given: Polish language, Polish history and geography,

Polish songs and dances

Sports instructions and training

Performances: organized 3 (choir and dances)

given 5

Sports competitions with English school teams: 18

(tennis, hockey, basket ball, netball).

Amount granted by Free Europe Citizen’s Service: $£ 335 \$ 940$

Expenses: (covered from grant made by Free Europe Citizens' Service):

(a) TEACHERS:

(1) 1 teacher (polish history, Polish language and

geography)

6 days per week

per 1 month:

$\$ 84$

per 6 months: $\quad \$ 504$

(2) 1 teacher (Polish songs and dances, sports

instruct.)

6 days per week

1 month:

$\$ 56$

6 months:

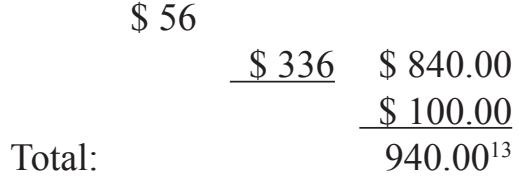

(b) CHILDREN'S POLISH LIBRARY:

${ }_{11}$ AGOG, sign. 318, Report Polish Schools in England, pp. 15; AAW, sign. 107, pp. 2.

${ }^{12}$ AGOG sign. 319, School for Polish Girls, Pittsford Hall, pp. 1-5; AAW, sign. 108, pp. 1-3; ACUA, sign. 501. 
SCHOOL FOR POLISH BOYS AT HEREFORD (ENGLAND)

Period: January - June, 1957

Primary School for 96 Polish boys (aged 6-12).

Lesson given: Polish language, Polish history and geography,

Polish national songs and dances

Sports instruct.

Performances: organized 2

given 3

Sports competitions with English school teams: 10

(netball, football, swimming, athletic sports).

Amount granted by Free Europe Citizen's Service: $£ 275 \$ 772.00$

Expenses: (covered from grant made by Free Europe Citizens' Service):

(a) TEACHERS:

(1) 1 teacher: Polish language. Polish history and

geography

6 days per week

per 1 month:

$\$ 84$

per 6 months:

$\$ 504.00$

(2) 1 teacher (Polish songs and dances, sports

instruct.)

3 days per week

per month:

$\$ 28$

per 6 months:

$168.00 \$ 672.00$

(b) CHILDREN'S LIBRARY:

Total:

$\$ 772.00^{14}$

SCHOOL FOR POLISH BOYS AT FAWLEY COURT (HENLEY-ON-THAMES)

ENGLAND

Period: January - June, 1957

Grammar School for 87 Polish boys (aged 11-18).

Lesson given: Polish language, Polish history and geography,

Polish choir

Sports instruct.

Performances: organized 6

given 6

Sports competitions with English school teams: 21

(boxing, rowing, swimming, football, netball, athletic sports).

Amount granted by Free Europe Citizen’s Service: $£ 275 \$ 772.00$ 
Expenses: covered from grant made by Free Europe Citizens' Service:

(a) TEACHERS:

(1) 1 teacher: Polish language. Polish history and geography

4 days per week

per month:

$\$ 70$

per 6 months:

$\$ 420.00$

(2) 1 teacher (Polish songs and dances, sports

$\$ 672.00$

instruct.)

3 days per week

per month:

$\$ 42$

per 6 months:

$\$ 252.00$

(b) LIBRARY FOR PUPILS:

$\$ 100.00$

Total:

$\$ 772.00^{15}$

\section{SUMMER CAMPS FOR POLISH CHILDREN AND YOUTH IN GREAT BRITAIN - 1958}

As a result of the generous help of the Free Europe Citizens' Service of the Free Europe Committee, Inc., it was again possible to organise a variety of camping holidays for Polish youth and children in Great Britain.

Camps were organized at a number of different sites, and the attached list " $\mathrm{A}$ " gives in detail the number of boys and girls who were able to benefit from these welcome holidays, which apart from the pleasures of life under canvas, included such enterprises as mountaineering, sailing on the Norfolk Broads, and deep sea yachting.

The sites chosen were in beautiful surroundings, on the banks of rivers or lakes, surrounded by wooded hills.

The camps varied in size, accommodating between children or young people. Each camp lasted from two to three weeks, and in some cases sites were used by two groups of young people in succession.

A very liberal subsidy from Free Europe Citizen's Service made it possible to purchase new equipment (e.g.).

This made a valuable addition to the camping and sports equipment provided by the Free Europe Citizens' Service in previous years, which, of course, was once again well used.

${ }_{13}$ AGOG, sign. 321, School for Polish Boys at Fawley Court, pp. 1-2; AAW, sign. 108, pp. 4; ACUA, sign. 501; ARN, Msgr. Gogoliński, pp. 14. 
When the children first arrived at the camps, some were unable to speak a word of Polish, others knew no English. ...children (... boys and ... girls) were the children of mixed merriages (Anglo-Polish and Scots-Polish) ... (... boys and ... girls) were children visiting this country from Poland, who had come to England with their parents to stay with relatives for a few months.

Polish language classes and Polish history lessons were held daily, and every evening there were talks on Poland - a memorable contribution to the atmosphere of all the camps. It was necessary to break down each community into separate groups, according to their age and their knowledge of the Polish language. Before the end of the camps, every child had learnt some basic words and could at least gather the gist of what was said to them in Polish.

\section{EXPENSES}

The cost of the camps was met by a subsidy of granted by the Free Europe Citizens' Service to Polish Caritas Abroad for allocation and administration.

Enclosure "B" lists in detail the full expenditure of this sum, a large proportion of which was spent on the following equipment:

tents

blankets

groundsheets

sports equipment

This equipment is being carefully stored, for future use by the Polish young people. ${ }^{14}$

\section{ACHIEVEMENTS}

The Polish atmosphere we had hoped to create in these camps was perhaps our happiest achievement.

As we have already mentioned, a number of the children to enjoy the camps were temporary visitors to Great Britain from Poland. Small groups of these children were allocated to different camps with very happy results, and we think they will long remember the atmosphere of Free Poland which for a time they were able to share.

The same atmosphere no doubt made just as much impression on some of the children of the mixed Polish - British marriages, who seemed to become aware of their Polish heritage for the first time.

Thanks to the subsidy, it was possible for ... young Polish people (... boys and ... girls) to come from France to stay at the camps, and ... Hungarian boys were also enabled to attend the camps and Scouts' Jamboree.

${ }^{14}$ AGOG, sign. 322, Summer Camps for Polish Children and Youth in Great Britain - 1958, Expenses, pp. 1-3; AAW, sign. 108, pp. 5-6. 
The letters of appreciation received from parents and the reports that appeared in the press confirm the sense of achievement that was felt by all the individuals who helped to administer the camps. We offer our sincere and grateful thanks to the Free Europe Citizens' Service of the Free Europe Committee, Inc., whose imaginative generosity made the Polish Summer Camps a happy reality.

The Summer Camps held in 1957 for Polish children and youth in Great Britain achieved highly successful results thanks to the generous help of the Free Europe Citizens' Service of the Free Europe Committee, Inc.

The results achieved exceeded all expectations and proved once again that the best means of arousing and maintaining the national spirit and sentiment in Polish children and youth is a sojourn in Polish Summer Camps organized for them.

The Polish children and young people who live in Great Britain and attend English schools, or are even boarded at public schools (i.e. private schools), know little or nothing of their own country's history or traditions and either forget their mother tongue or cannot speak or understand it at all.

At the Summer Camps organized for them they are in a thoroughly Polish atmosphere. In all the camps courses are organized in the Polish language and in Polish literature and history, and the children and youth attending the camps are provided also with every opportunity of learning Polish songs and dances.

The selection and training of individuals from among the older participants who are suitable to become future leaders and instructors of the rising generations in the love of their fatherland's traditions, customs and language is one of the most important missions of these Summer Camps.

The present leaders of the Camps are experience instructors and teachers, drawn mostly from the Polish Scouting and Girl Guides Movements, whose time and labour is unpaid and given entirely voluntarily. (Their travel and other essential out - of - pocket expenses will, of course be reimbursed).

A strict daily syllabus to ensure that the time spent in the Camps is fully exploited for the achievement of their purpose is laid down in the Regulations.

Quite unanticipated success has been achieved to date in fostering the national spirit among the Polish children and youth attending these camps.

The intention is to organize at least the same number of Summer Camps in 1958 as in 1957 ( 25 camps).

Each group of children and youth will spend at least a fortnight in one of the camps. (Three camps will take two successive groups).

Because of the general conditions of the Polish Community in Great Britain the charge for attending the camps is very low and is barely sufficient to cover the costs of maintenance. Even this small charge is more than many of the parents can 
afford, and therefore many of the Polish children and youth have to forego even so cheap and fruitful a holiday.

Of necessity, the fare provided in the Camps, though healthy, is hardly sufficient for growing boys and girls. The supply of equipment for indoor and outdoor sports and games and of books for study and reading is still inadequate in spite of the great investment made last year thanks to the generosity of Free Europe Citizens' Service.

It is also desirable to have some small funds for the provision of prizes for sports and other competitions.

(The yachting and mountaineering groups are considered to be of special importance because of the attraction they have for young persons aged between 17 and 25 who, coming from outlying places, return home spiritually strenghend in Polish traditions). ${ }^{15}$

\section{CHILDREN FROM POLAND}

In 1957 there were 66 children in our Summer Camps who came from Poland to Great Britain on visits to their relatives. We are firmly convinced that if we receive help from Free Europe Citizens' Services we shall be able take another 80-100 such children into our Camps in 1958.

They will not make a separate group but small groups of them will be allocated to various camps as last years experience shows this to have been an exceedingly advantageous arrangement.

It goes without saying that the subsidy per capita for these children (from Poland) will have to be higher; that is to say, their families will naturally be able to make only a smaller contribution to their maintainance in the camps. If a special fund is granted for this purpose a souvenir will be handed to each of these children at the close of the Camps, which it was impossible to do last year for lack of funds.

The Summer Camps held in 1957 for Polish children and youth in Great Britain achieved highly successful results thanks to the generous help of the Free Europe Citizens Services of the Free Europe Citizens' Services of Free Europe Committee, Inc.

The results achieved exceeded all expectations and proved once again that the best means of arousing and maintaining the national spirit and sentiment in Polish children and youth is a sojourn in Polish Summer Camps organized for them.

The Polish children and young people who live in Great Britain and attend English schools, or are even boarded at public schools (i.e. private schools), know little or nothing of their own country's history or traditions and either forget their mother tongue or cannot speak or understand it at all.

\footnotetext{
15 AGOG, sign. 323, Achivements, Polish Scouting, pp. 1-4; AAW, sign. 108, pp. 7.
} 
At the Summer Camps organized for them they are in a thoroughly Polish atmosphere. In all the camps courses are organized in the Polish language and in Polish literature and history, and the children and youth attending the camps are provided also with every opportunity of learning Polish songs and dances.

The selection and training of individuals from among the older participants who are suitable to become future leaders and instructors of the rising generations in the love of their fatherland's traditions, customs and language is one of the most important missions of these Summer Camps.

The present leaders of the Camps are experienced instructors and teachers, drawn mostly from the Polish Scouting and Girl Guides Movements, whose time and labor is unpaid and given entirely voluntarily. (Their travel and other essential out-of-pocket expenses will, of course be reimbursed).

A strict daily syllabus to ensure that the time spent in the Camps is fully exploited for the achievement of their purpose is laid down in the Regulations.

Quite unanticipated success has been achieved to date in fostering the national spirit among the Polish children and youth attending these camps.

The intention is to organize at least the same number of Summer Camps in 1958 as in 1957.

Each group will spend a fortnight in one of the camps. (The Delamere Park and Canvey Island Camps will take two successive groups).

Because of the general poverty of the Polish Community in Great Britain the charge for attending the camps is very low and is barely sufficient to cover the costs of maintenance. Even this small charge is more than many of the parents can afford, and therefore many of the Polish children and youth have to forego even so cheap and fruitful a holiday.

Of necessity, the fare provided in the Camps, though healthy, is hardly sufficient for growing boys and girls. The supply of equipment for indoor and outdoor sports and games and of books for study and reading is still inadequate in spite of the great investment made last year thanks to the generosity of Free Europe Citizens' Services.

It is also desirable to have some small funds for the provision of prizes for sports and other competitions.

(The yachting and mountaineering groups are considered to be of special importance because of the attraction they have for young persons aged between 17 and 25 who, coming from outlying places, return home spiritually strengthened in Polish traditions).

In 1957 there were 106 children in our Summer Camps who came from Poland to Great Britain on visits to their relatives. We are firmly convinced that if we receive help from Free Europe Citizens' Services we shall be able to take another 
80-100 such children into our Camps in 1958. They will not make a separate group but small groups of them will be allocated to various camp as last year's experience shows this to have been an exceedingly advantageous arrangement.

It goes without saying that the subsidy per capita for these children will have to be higher; that is to say, their families will naturally be able to make only a smaller contribution to their maintenance in the camps. If a special fund is granted for this purpose a souvenir will be handed to each of these children at the close of the camps, which it was impossible to do last year for lack of funds.

A list of the Camps giving particulars of the localities and the number and ages of the participants is attached.

An estimate of the minimum help required is also attached.

For the improvement of alimentation, refund of instructors' out - of - pocket expenses, and subsidy for children and young people who cannot afford to pay and those who cannot afford to pay at all, the requirement per capita, i.e. for each participant, will be at least $\$ 3.00$.

As it is anticipated that the attendance at this year's Summer Camps will exceed 2,000 participants, we wish to apply most earnestly for the grant of a subsidy of at least $\$ 6,000 .{ }^{16}$

\section{ESTIMATED EXPENSES}

\section{Personal expenses}

Improvement of alimentation -

Subsidies for children and youth who cannot pay at all or who cannot $\$ 6,000.00$ afford to pay fully charges -

Payments of Instructors' out-of-pocket expenses:

2,000 participants - per capita - \$3 each:

Equipment

tents, blankets etc.

$1,000.00$

sports equipment

500.00

books

300.00

prizes for sport or other competitions

200.00

Expenses Total:

$\$ 8,000.00$

${ }^{16}$ AGOG, sign. 324, Children from Poland 1957-1958, Estimated Expenses, Free Europe Citizens' Services, pp. 1-6; AAW, sign. 109, pp. 1-2; ACUA, sign. 502. 


\section{SUMMER CAMPS FOR POLISH CHILDREN AND YOUTH IN GREAT BRITAIN - 1960}

The Polish children and young people who live in Great Britain and attend English schools, or are even boarded at public schools (i.e. private schools), know little or nothing of their own country's history or traditions and either forget their mother tongue or cannot speak or understand it at all.

At the Summer Camps organized for them they are in a thoroughly Polish atmosphere. In all the camps courses are organized in the Polish language and in Polish literature and history, and the children and youth attending the camps are also provided with every opportunity of learning Polish songs and dances.

The selection and training of individuals from among the older participants who are suitable to become future leaders and instructors of the rising generations in the love of their fatherland's traditions, customs and language, is one of the most important missions of these Summer Camps.

The present leaders of the Camps are experienced instructors and teachers, drawn mostly from the Polish Scouting and Girl Guide Movements, whose time and labour is unpaid and given entirely voluntarily. (Their travel and other essential out-of-pocket expenses will, of course, be reimbursed).

A strict daily syllabus to ensure that the time spent in the Camps is fully exploited for the achievement of their purpose is laid down in the Regulations.

The intention is to organize at least 12 Camps in 1960 for at least 1,200 children, covering the period July 30 to August 28, 1960.

Each group of children and youth will spend at least a fortnight in camp.

The charge for attending the camps is very low and is barely sufficient to cover the costs of maintenance. Even this small charge is more than many of the children can afford, and therefore many of the Polish children lose the opportunity of this holiday.

Of necessity, the fare provided in the Camps, although healthy, is hardly sufficient for growing boys and girls. The supply of equipment for indoor and outdoor sports and games, and of books for study and reading, is still inadequate in spite of the large investment made in previous years, thanks to the generosity of Free Europe Organizations \& Publications.

It is also desirable to have some small fund for the provision of prizes for sports and other competitions.

(The yachting and mountaineering groups are considered to be of special importance because of the attraction they have for young persons between the ages of 17 and 25 who, coming from outlying places, return home spiritually strengthened in Polish traditions). 


\section{CHILDREN FROM POLAND}

According to the previous years' experience, it is expected that there will be staying in the Camps about 50 children who are coming from Poland this year to visit their relatives in Great Britain.

It is further estimated that these children will be visited in the camps by 100 other Polish children who are also visitors to this country from Poland. ${ }^{17}$

\section{ESTIMATED EXPENSES}

For the improvement of alimentation, refund of and young people who cannot afford to pay full charges and for those who cannot afford to pay at all, the requirements per capita, i.e. for each participant, will be at least: $\$ 3$.

As it is anticipated that the attendance at this year's Summer Camps will exceed 1,200 participants, we wish most earnestly to apply for the grant of a subsidy of at least: $\$ 3,600.00$.

\section{THE POLISH CONSULATES’ PROPAGANDA ACTIVITIES}

The Polish Consulates here are already sending out propaganda enticing parents to send their children to Poland for the holidays.

If we are unable to accomodate all the children and young people at the camps, there is a serious risk that many parents of children who would otherwise have to remain in the cities for the whole of the summer will succumb to the temptation to send their children to these camps in Poland. In spite of the assurances of the Consulates that their camps will not be of a political nature, it is a know fact that their camps are conducted by communists. We fear that the young people who go to Poland will return from there with the seeds of communism which we are fighting here.

We would point out that the Camps we conducted in previous years rendered it quite impossible for the Consulates here to enlist children for summer holidays in Poland.

Polish Caritas in Great Britain will, as previously, make itself responsible for the administration of any subsidy granted and will send detailed accounts of expenditure together with the relevant supporting vouchers.

Narrative reports will also be prepared in due course and despatched with accompanying photographs, etc. ${ }^{18}$

We have presented our case. We would be very grateful if Free Europe Organizations \& Publications of the Free Europe Committee, Inc., could help us by

17 AGOG, sign. 325, Summer Camps for Polish Children and Youth in Great Britain July 30 to August, 1960, pp. 1-3; AAW, sign. 110, pp. 1-2.

${ }^{18}$ AGOG, sign. 326, The Polish Consulates' Propaganda Activities, Free Europe Organizations $\&$ Publications of the Free Europe Committee, Inc., pp. 1-2; AAW, sign. 111, pp. 1-2. 
a single grant of a sum sufficient to enable us to create and run the above mentioned projects, the sum of $\$ 3,600.00$.

\section{SUMMER CAMPS FOR POLISH YOUTH IN GREAT BRITAIN - 1961}

The Polish children and youth residing in Great Britain and attending English schools, or even boarding at public schools, forget their mother tongue, and often cannot speak it or understand it at all. They do not know their country's history or its traditions.

At the Summer Camps organized for them they are in a thoroughly Polish atmosphere. In all the camps courses are organized in the Polish language and in Polish literature and history, and youth attending the camps are provided also with every opportunity of learning Polish songs and dances.

The selection and training of individuals from among the older participants who are suitable to become future leaders and instructors of the rising generations in the love of their fatherland's traditions, customs and language is one of the most important missions of these Summer Camps.

We shall be grateful for the grant of a subsidy to enable us to send as many young people as possible to this year's Summer Camps. The numbers who can be sent to the Camps will be dependent on the amount of the subsidy granted.

We anticipate that just as in previous years, children for Poland will be also attend our Summer Camps (in 1957 there were 66 children form Poland, in 19608 children).

Except for the children from Poland, the young people pay for their maintainance and the subsidy is necessary mainly for equipment and instruction.

Thanks to Free Europe Organizations and Publications 36 Polish girls were trained at Lilgford last year. So 36 new young Polish leaders came from this camp and are working among Polish youth in this country now, inspiring them with the spirit of the best traditions of the Polish nation. ${ }^{19}$

\section{SUMMER CAMPS FOR POLISH YOUTH IN GREAT BRITAIN - 1962}

As in previous years, with the generous help of Free Europe Organizations and Publications, it was possible last year also for Caritas to organize Summer Camps for Polish children and young people living in Great Britain.

Providing, as they do, a completely Polish atmosphere, these Camps have proved to be of the greatest value in stimulating the national spirit of Polish youth. The children, who normally attend English schools, know little of their mother

19 AGOG, sign. 326, Summer Camps for Polsh Youth in Great Britain 1961, pp. 1; AAW, sign. 112, pp. 1-2. 
tongue or of the history and traditions of Poland, but at the Summer Camps they learn to feel that they are Polish. While enjoying all the pleasures of a camping holiday, they are eager to learn the songs and dances of Poland and welcome the opportunity of attending the courses in Polish language and literature and history which are always arranged at the Camps.

The leaders of the camps are experienced teachers and instructors. A daily programme is arranged so that the time can be used to the best possible advantage.

From the end of July to the end of August 1962, two successive camps of two weeks duration will be held. We expect to have 200 children in our Summer Camps this year and we anticipate that, as in previous years, a number of children from Poland will be able to attend.

Our estimate for our Summer Camps in 1962:

(A) Maintenance:

Additional payment for improvement of

alimentation

( 1 per capita per week) 4 weeks:

$£ 400$

Subsidies for children who cannot afford to pay

full charges

$£ 100$

(B) Education etc.

(1) Teachers and instructors:

Camp leader (£ 12 p.w.) 4 weeks

$£ 48$

2 teachers Polish: language, literature, history

and Polish songs

(each $£ 11$ p.w.) 4 weeks

$£ 88$

2 instructors in physical training (plus Polish

dances)

(each $£ 10$ p.w.) 4 weeks

$£ 80$

(2) Equipment (sport \& indoor games)

$£ 40$

(3) Shows and festivals: costumes and decorations

$£ 30$

(4) 4 excursions in Polish style (coach)

$£ 60$

(5) Polish books for Camp library

$£ 30$

(6) Prizes: for Polish language, history.

For Polish songs and folk dances.

Sports competition.

$£ 30$

(7) 4 cinema performances

$£ 20$

(8) Incidental expenses

Total: $\stackrel{£ 20}{£ 4446} \frac{(\$ 1,248)}{(\$ 2,648)}$

As our organization cannot afford the whole of the money necessary we shall be most grateful if a grant of $\$ 1,000$ can be allocated towards our expenses - par- 
ticularly the expenses which are not connected with food and maintenance (i.e. teachers, instructors, equipment etc.), without which the whole aim and object of the Camps would fail completely. ${ }^{20}$

\section{VISIT OF POLISH BOYS FROM FRANCE TO GREAT BRITAIN REQUEST FOR GRANT}

We are organizing a cycling holiday in Great Britain, for Polish boys who are pupils in modern schools, grammar schools and high school, in Northern France. Age of the boys 14-18 years. Number of boys limited to 40 .

The party will start their bicycle journey from Vaudricourt (Bethune) (Pas-deCalais), at the end of July. They will be in this country for 4 weeks and will cycle in England and Wales, travelling as far as Scotland if time permits.

Their route will commence from Folkestone, through London, Oxford, Gloucester and Bristol to Cornwall, where they will campo for a while. Continuing their journey they will travel through Wales to Lancaster, York, Lincoln and Cambridge.

The boys will be in the care of 2-3 qualified Polish teachers, and will be visiting museums, galleries and famous building throughout their journey. But first and foremost, they will visit General Sikorski's Institute and other Polish institutions in London. During the journey there will be lectures on Polish literature and history, and the boys will be obliged to speak Polish during the entire four weeks.

The party will contact the Polish community in London and other places and with performances by their choir and their team of Polish folk dancers, will take part in local Polish entertainments.

Those taking part in this adventure are being very carefully selected as boys who are distinguished for their intelligence and are considered to be potential leaders, first, of Polish youth in their own districts, and later, of the Polish community through France.

ESTIMATED EXPENSES:

$$
1 \text { person } \quad 40 \text { persons }
$$

per 4 weeks

$£ \quad \$ \quad £ \quad \$$

(a) Food and maintenance

$\begin{array}{lllll}(£ 4-\$ 11.20 \text { per person per week) } & 16 & 44.80 & 640 & 1,792\end{array}$

(b) Various expehses

(£0.10.0-\$1.40 per person per week)

$2 \quad 5.60 \quad 80 \quad 224$

Total: $\quad £ 18 \quad \$ 50.40 \quad £ 720 \quad \$ 2,016$

${ }^{20}$ AGOG, sign. 327, Summer Camps for Polish Youth in Great Britain 1962, pp. 1-5; AAW, sign. 113, pp. 2-3. 
Although the boys have been saving up for this tour from the beginning of the current school year (September 1961), unfortunately they will not be able to pay all their expenses. Our organization will be able to assist them from our own funds, but the sum raised by the boys and Caritas together will not exceed $\$ 1,000-\$ 1,100$.

Only the allocation of a grant for this experiment will make it possible to bring 40 Polish boys from France to Great Britain. The project would most certainly be a useful one, not only for the boys themselves but also for the various centres of the Polish Community in Great Britain and for the Polish Community in France. But it is of prime importance for the life of the Polish Community in France in the near future, that these boys should come here and have some experience of the well organized Polish community life in Great Britain. For this reason we are approaching your organization (Free Europe Organizations and Publications), asking you to allocate the sum of $\$ 1,000$ for the purpose above mentioned. ${ }^{21}$

\section{SUMMER VACATIONS OF POLISH EMIGRANT YOUTH EXCURSION TO POLAND - REQUEST FOR GRANT}

Our organization has reached an advanced stage in efforts to organize a holiday excursion to Poland of Polish girl students from Great Britain.

The obvious object of this excursion is to show Poland to the Polish girls, to acquaint them with its scenery, with its main towns such as Warsaw, Krakow, Poznan, Gdansk, etc., and with the country's museums, art galleries and the like.

This "official" object is not, however, the only reason for organizing this enterprise.

The Primate of Poland, Cardinal Wyszynski, during his latest visit to Rome in February 1962, himself suggested the organization of such excursions, being of the opinion that the very presence of young Polish people from England would do good not only to themselves but - a point which the Cardinal particularly emphasized also to that part of the populace of Poland which comes directly or indirectly into contact with the new Polish emigrants from abroad.

So far, 35 girls who are being educated at English schools have enlisted to take part in the excursion. They are from 14 to 17 years of age. The intention is to stay in Poland for 4 weeks, one week of which the girls would spend in the homes of their relatives.

The excursion will set off for Poland by train on $3^{\text {rd }}$ August, arriving at Poznan whence they are to tour Poland by coach. Three Polish nuns from England will be

${ }^{21}$ AGOG, sign. 328, Visit of Polish Boys from France to Great Britain, pp. 1-6; AAW, sign. 114, pp. 1-3; ACUA, sign. 503. 
in charge of the excursion and will see to it that no communist influences affect the young people.

The estimated expenses are:

1. Return railway tickets from London to Poland

2. (Poznan).

3 weeks' stay in Poland:

Board and lodging, coach, visits to museums

etc., tickets on the mountain railway at

Zakopane, guides, porters, etc.

$$
\text { Total: } \frac{\$ 135}{\$ 135} \quad \frac{\$ 3,500}{\$ 4,725}
$$

Unfortunately, the girls themselves cannot afford the whole of the costs. Some of them are able to cover only $50 \%$ of the expenses, others (and the most sterling and intelligent among them at that), cannot afford anything at all to enable them to take part in the excursion.

We are therefore submitting to you our earnest request for financial aid amounting to $\$ 1700$ which will enable us to organize the excursion and ensure its complete success; the attainment of its objects depends entirely on the subsidy for which we are applying to your organization..$^{22}$

Our estimate for our Summer Camps in 1962:

(A) Maintenance

Additional payment for improvement of

alimentation.

(£ 1 per capita per week) 4 weeks:

Subsidies for children who cannot afford to pay full

(B) Charges

$\underline{£ 100} £ 500 \$ 1,400$

Education etc.

(1) Teachers \& instructors:

Head tutor (£12 p.w.)

(2) 2 teachers (Polish language, literature, history and Polish songs)

(each $£ 11$ p.w.

(3) 2 physical training instructors (\& Polish dances) $£ 88$ (each $£ 10$ p.w.)

${ }^{22}$ AGOG, sign. 329, Summer Vacations of Polish Emigrant Youth. Excursion to Poland, pp. 1-3; AAW, sign. 115, pp. 1-2. 
POLES IN ITALY

\section{APPROXIMATE AMOUNT}

1. Two orphanages (for orphans and dependent children)

2. Summer camps and recreation centres for 150 children

3. Travelling expenses of Rev. W. Rubin, as lecturer to the Poles in all districta of Italy

$\$ 5,000.00$ per annum

$2,000.00$

500.00

4. Publication of "RODAK," a bi-weekly release for Radio stations to help stop infiltration and spread of communism

5. "MILLENIUM" - buy 20 copies of each volume, as published for distribution to Polish libraries and cultural centres

6. Salary of Polish Instructor of cultural and national questions at the Polish Pontifical College in Rome

7. Two halls for social meetings of the Poles:
(a) ROME: rent
$1,000.00$
furnishings and
maintenance
journals, books, magazines,
etc.
$4,000.00$
$1,000.00$
(b) LORETO: rent
500.00
furnishings and
maintenance
500.00
books, periodicals, etc.
200.00

\section{LIBRARIES:}

$7,200.00$

(a) Two fixed libraries - Rome and Loreto: 2,000.00

(b) Mobile libraries -8 - Torino, Milano, Arezzo, Bologna, Forli, Firenze, Aversa, Lecce

TOTAL:

$5,000.00$

$\$ 23,200.00$ per annum

There are at present about 500 Poles in Italy for whose children there exist two Polish schools:

(a) Loreto - Ancona (Via Delle Casette 7): for boys (30 boys aged 7-13),

(b) Rome (Via Marcantonio Colonna 52): for girls (30 girls aged 7-12). 
In these schools the children learn the Polish language, Polish history, geography, and also Polish songs and dances.

Teaching is carried on in these schools on all week days for 6 days in the week, while on Sundays the schools become a recreational centre for the children (indoor and outdoor games, sports competitions, outings, theatrical performances, and the like).

The expenses in each school are as follows: (6 months period January - June 1957

(a) TEACHER: One teacher working 7 days per

week (full time job). Teacher's

salary amounts per month:

Ital. lire: $50.000-\$ 80.00 \quad$ It. lire: $300.000 \$ 480.00$

(b) EQUIPMENT: Basic equipment requires - at

least:

$19.000 \quad 30.00$

(c) CHILDREN'S LIBRARY:

Initial purchase of several dozens

of books in Polish for the children

is estimated at:

$31.000 \quad 50.00$

Total (for each school): lire: $\quad 350.00 \$ 560.00$

The premises are provided in each case by Polish religious congregations which are, however, not in a position to cover the expenses incurred in the running of the schools. ${ }^{23}$

Any financial help from Poland is out of the question for well known reasons.

Almost without exception, the children's presents (most of children are semi-orphans) cannot obtain any employment at all in Italy, and even if they have work their pay is so small that it barely suffices for maintenance of the family. That is the reason why none of the parents pay for their children's education.

The above mentioned schools (Rome and Lorento - Ancona) have so far been barely able to carry on but now, despite the utmost efforts of Polish Caritas Abroad through which they are run both these schools are threatened with closure through absolute lack of funds for their conduct. Unfortunately, Polish Caritas Abroad is not at present able to help these schools. Yet it would seem to be essential to keep the schools running until the end of the school year, i.e. for a period of 6 months (January to June 1957).

The performances in which the children appear (concerts of Polish songs, dances etc.) have not only been a great attraction for the Polish community in Italy, but have also played a great part in upholding the national spirit of the Poles in Italy.

${ }^{23}$ AGOG, sign. 330, Poles in Italy, War Relief Services-NCWC Italy, pp. 1-3: AAW, sign. 116, pp. 1-2. 
It should be mentioned that on several occasios the consulates of the Polish communist regime have offered substantial help to the above mentioned schools, but these offers have been categorically rejected.

In view of the importance of the problem and, above all, in view of the complete denationalisation which threatens the Polish children in Italy, we beg you most kindly for help in the running of these Polish schools in Italy as the schools will have to close if help is not received.

The Head Office of the Polish Caritas Abroad (London) will be responsible for the despatch to Free Europe Citizens' Service of detailed monthly reports together with vouchers duly approved and signed.

We would ask kindly for grants of:

$\$ 560.00$ (It. lire: 350.000 ) for the school for Polish boys in Loreto Ancona), and

(b) $\$ 560.00$ (It. lire: 350.000$)$ for the school for Polish girls in Rome).

Total: $\$ 1120.00$ (It. lire: 700.000 ).

Your generosity in making grants to the amount of $\$ 1,120.00$ will save the schools from closing and will enable them to continue work until the end of June 1957.

There are two schools for Polish children in Italy which were supported from Free Europe Citizens' Service grants by Polish Caritas Abroad:

(1) a school in Loretto for boys (Via delle Casette 7): for 32 boys (aged 7-13); (2) a school in Rome for girls (Via Marcantonio 52): $\quad$ for 35 girls (aged 7-12).

In these schools the children learn the Polish language, Polish history, geography, and also Polish songs and dances.

Teaching was carried on in these schools on all week days for 6 days in the week, while on Sundays the schools became a recreational centres for the children (indoor and outdoor games, sports competitions, outings, theatrical performances and the like).

The premises were provided in each case by Polish religious congregations which were, however, not in a position to cover all the expenses incurred in the running of the schools.

Almost without exception, the children's parents (most of the children are semi-orphans) could not obtain any employment at all in Italy, and even if they had work their pay was so small that it barely sufficed for maintenance of the family. That is the reason why none of the parents paid for their children's education in Polish subjects.

These schools were threatened with closure for lack of funds and were able to carry on from January until June, 1957, thanks to the generous help of Free Europe Citizens' Service. 
The continued existence of these schools was salutary not only for the education of the children but, in general, to the national life of the small Polish community in Italy; for the children's performances at national gatherings were an attraction and encouragement to their elders.

Thanks to the training of the children in the national spirit in the schools, both they and the Polish adult community have been meantime saved from the denationalization which threatens them to the highest degree in Italy.

Of even greater importance is the fact that the support given to these two schools circumvented the presistent efforts of the Polish Communist Consulate to take them over ot create their own schools as a counter-attraction.

Attached please find 2 separate financial reports concerning the uses to which the funds received from Free Europe Citizens' Service were put in each of these schools during the period concerned (January-June, 1957).

We thank you most heartily for enabling this good work to continue, the lack of which would have been highly detrimental to the life of the Polish community in Italy, and which could absolutely not have been carried on without Free Europe Citizens' Service very kind and very generous support. ${ }^{24}$

\section{SCHOOL FOR POLISH BOYS IN LORETO - ANCONA, ITALY}

32 Boys aged 7-13.

Period: $\quad$ January - June, 1957, (six months).

Lessons given: Polish language, Polish history and geography;

Polish songs and dance.

3 performances organized and 6 given (twice each).

Amount of grant from Free Europe Citizens' Service: \$ 560.00 (Lire: 350.000 )

EXPENSES: $:^{25}$

(a) TEACHER: One teacher working 7 days

per week (full time job)

a $\$ 80$ per months: 6 months:

$\$ 480.00$

(b) SCHOOL EQUIPMENT: (basic):

20.00

(c) CHILDREN'S LIBRARY:

(d) COST of PERFORMANCES (costumes, scenary, and travel expenses)

${ }^{24}$ AGOG, sign. 330, pp. 3-4; ACUA, pp. 501; ARN, Msgr Gogoliński, pp. 11-12.

${ }^{25}$ AGOG, sign. 331, School for Polish in Loreto, Ancona. pp. 1; AAW, sign. 117, pp. 1-2. 


\section{SCHOOL FOR POLISH GIRLS IN ROME (ITALY) ${ }^{26}$}

35 Polish girls aged $7-12$.

Period: $\quad$ January - June, 1957.

Lessons given: Polish language, Polish history and geography;

Polish songs and dances.

3 performance organized and 4 given.

Amount of grant made by Free Europe Citizens' Service: $\$ 560.00$.

EXPENSES

(a) TEACHER: One teacher working 7 days per week (full time job)

Teacher's salary: per month $\$ 80.00$ for 6 months: $\quad \$ 480.00$

(b) SCHOOL EQUIPMENT: (basic):

22.50

(c) CHILDREN'S LIBRARY:

(d) COST of PERFORMANCES

(costumes, scenary)

Total: $\quad \frac{12.50}{\$ 560.00}$

POLISH CATHOLIC CARITAS IN DENMARK - 1956

Polish Caritas in Denmark directs its social work towards organizing the, roughly, 10,000 Poles in this country.

Lack of appropriate and sufficient means automatically limits our possibilities and renders impossible the development of an activity which we consider of the greatest importance in maintaining the national spirit of our people whom numerous agitators are continually trying to beguile, by every possible means, away from their national tradition and way of living. By weakening the national spirit of the Poles room is made for alien indoctrination and no effort is spared in this direction.

It is absolutely necessary to set up for Poles in Denmark, the following:

(1) 10 Mobile Polish Libraries

(the cost of each of them would be:

Dkr. 1150 - USD 160.00) Dkr. 11500 USD 1,600.00

(2) To organize lectures, discussion meeting, commemorative meetings etc. in 15 localities in Denmark inhabited by Poles): 6600 924.00

(3) To organize and maintain a Polish youth choral and theatrical club, which would take part in commemorative meetings in these various localities, etc.

\begin{tabular}{|c|c|c|}
\hline & 6740 & 990.00 \\
\hline & Dkr. 2484 & USD 3,5 \\
\hline
\end{tabular}

${ }^{26}$ AGOG, sign. 332, School for Polish Girls in Rome, pp. 1; AAW, sign. 118, pp. 1-2. 
Polish Caritas in Denmark undertakes the responsibility of carrying out the above mentioned activities which will no doubt be of great help towards the preservation of national morale among Poles here.

Polish Caritas undertakes to administrator funds for the purpose in accordance with instructions received. Reports accompanied by vouchers will be returned within the prescribed time.

We shall be most grateful to Free Europe Citizen's Service we have herewith the honour to request. ${ }^{27}$

\section{PROJECT: POLISH MOBILE LIBRARIES IN DENMARK}

For 10,000 Poles in Denmark a question of maintaining a live contact with their national culture is of a great importance not only with regard to their spiritual welfare but also because of the great role played by this culture in strengthening their inner resistance to the communist propaganda.

Polish books, especially classical works of Sienkiewicz, Mickiewicz, etc. are the means by which these ends can be most easily approached. It could be done by the creation and organization of Polish mobile libraries containing 50-60 books each, housed in separate cases and consisting of totally different sets of books.

Depending on the grants received, from 15 to 25 such libraries should be formed. They would be sent to places where is a considerable number of Poles. Every few months the libraries would be exchanged amongst the different localities to enable the Poles in each place to obtain fresh books.

If you considered it desirable and proper all libraries would bear the name: "Free Europe Citizen's Service - Mobile Library for Poles in Denmark" or similar.

All the books will be properly labelled and rubber - stamped.

Polish Caritas in Denmark will undertake the organization and administration of the libraries.

The estimated cost of one mobile library is as follows:

(1) Books (50-60):

Dkr. 1000 USD 140.00

(2) Wooden case for books:

100

14.00

(3) Administrative expenses:

$50 \quad 6.00$

Total: Dkr. 1150 USD 160.00

We have presented our case. We would be very grateful if Free Europe Citizens' Service of Free Europe Committee, Inc. could help us by a single grant of a sum

${ }^{27}$ AGOG, sign. 333, Polish Catholic Caritas in Denmark 1956, pp. 1-2; AAW, sign. 119, pp. 1; ACUA, sign. 504; ARN, Msgr Gogoliński, pp. 16. 
sufficient to enable us to create of 10 (ten) Polish mobile libraries at a total cost of Dks. 11500 - USD 1,600.00. ${ }^{28}$

\section{PROJECT: POLISH COMMUNITY DISCUSSION MEETINGS}

Communist consulates behind the Iron Curtain have been busily trying for a considerable time to infiltrate the Polish community in Denmark. There is close evidence of the activity of agencies of the Polish communist consulate in that they are continually making efforts to establish contact with the Poles here.

So far their activities have fortunately met with little response, but lately it is being feared that the Poles are gradually becoming less immune to these advances. The main reason is the lack of close personal contact among the Poles here.

Many factors contributed to this state of affairs, but this is no place to enumerate them. It is a fact that, with the exception of Copenhagen, no meetings or national celebrations were ever held by Poles at any other place in Denmark.

Agents of the Polish communist consulate arrange public meetings for Poles in various localities in Denmark, but they cannot be too satisfied with their results, as only a small fraction respond to their importunate invitations.

The Poles, however, are willing to meet each other and it is necessary to give them the opportunity of public meetings in order, for example, that may listen to a lecture or a speach, discuss actual problems and even to sing together Polish national and folk songs.

It is strongly advocated that such meetings should be held for the Poles here twice or, at the very least, once a month. ${ }^{29}$

The Executive Committee of Polish Caritas in Denmark is only too anxious to counteract the work of the consulate's agents. Polish Caritas has possibility of arranging such meetings and making them attractive and interesting by inviting lectures and including community singing or a concert of recorded Polish music or by showing lantern slides or even suitable films.

We lack, however, the necessary means in order that we may realize our aims. We must have funds to cover expenses such as travel of lecturers and their Per Diem allowance.

It is also indispensable to supplement our equipment in order that the proposed activities may be carried out.

${ }^{28}$ AGOG, sign. 334, Project Polish Mobile Libraries in Denmark, pp. 1-3; AAW. sign. 120, pp. 1-2.

${ }^{29}$ AGOG, sign. 335, Project Polish Community Discussion Meetings, pp. 1-4; AAW, sign. 121, pp. 1-2. 
Please find enclosed list of 15 localities where we would like to hold periodical meetings for Poles, stating all estimated expenses of lecture. The estimated total of these expenses for the period of 8 months (November 1956 - June 1957) amount to: Dkr. 4000 (USD 560.00).

To this we must add the cost of supplementary equipment, administrative and other expenses:

A. (1) Cost of traveling of lectures for 76 meetings

(Period: 8 months: November 1956 - June 1957): Dkr 2400 USD 336.00

(2) Lecturers' Per Diem (76 meetings): $\quad 1600 \quad 224.00$

B. Equipment:

924.00

C. (gramophone and records, epidiscope, lantern slides, music etc.):

\begin{tabular}{rr}
2000 & 280.00 \\
660 & 280.00 \\
\hline
\end{tabular}

Administrative and other expenses:

Grand total: Dkr. 6600 USD 924.00

We shall be deeply grateful for a grant for these purposes which will enable us to paralise the work of highly undesirable elements, who otherwise may be successful in widening the breaches already made with out a check to their nefarious activities. It is a great pity that lack of funds thus play into their hands.

We sincerely trust that the Free Europe Citizens' Service of Free Europe Committee, Inc., will see their way to helping us with the above mentioned grant of Dkr. 6600 - USD $924.00 .{ }^{30}$

\section{PROJECT: POLISH YOUTH CHORAL AND THEATRICAL CLUB}

There is, at present, no Polish theatre in Denmark. This is felt to be a serious lack in the life of the Polish community there.

Polish youth, cared for by the Polish Caritas in Denmark, would willingly join a Polish choral and theatrical club if such could be created.

The Polish Caritas in Denmark would eagerly undertake to organize such a Club for the Polish Youth. One Club, for the present, could be created in Copenhagen. Later on, others could follow in these places where there are the biggest communities of Poles in Denmark.

The club in question would be composed of two sections: choral and theatrical. The choral section would cultivate mostly Polish national and folks' songs. Analogically the repertory of the theatrical section would be based principally on Polish national and patriotic pieces. It would include recitations both prose and poetic. The club members would also cultivate Polish national and folk dances.

${ }^{30}$ AGOG, sign. 336, The Executive Committee of Polish Caritas in Denmark, pp. 1-2; AAW, sign. 122, pp. 2-3. 
Both sections, together and separately, would take part in Polish meetings and rallies, national days celebrations, etc. Thus those meetings would become much more interesting and attractive. Songs for choral and soloist parts, stage folks dances, presentations of short dramatic pieces, recitations - all of those would serve to deepen and strenghten the morale and patriotic feelings of Poles in Denmark.

Both sections would be mobile and would visit fairly frequently provincial Polish centers. During the next 8 months (November 1956 - June 1957) at least 10 such visits would take place.

Organization and running of the club would necessitate some inavoidable expenses. Among the most necessary are the costs of theatrical and dancing costumes and dresses (mostly national and folks'), some stage accessories ("make - up" rouges and pensils), some simple decorations, etc.

Visits to the Polish outside Copenhagen communities will bring some travel (rail and bus) expenses. ${ }^{31}$

\section{ESTIMATED EXPENSES OF THE POLISH YOUTH CHORAL AND THEATRICAL} CLUB:

(1) Theatrical costumes, national and folks dresses: Dkr. 2040 USD 300.00

(2) Theatrical accessories: $680 \quad 100.00$

(3) Decorations: $340 \quad 50.00$

(4) Music, theatrical library $340 \quad 50.00$

(5) Travel expenses (each at Dkr. 300 - USD 44.00): 3000

(6) Administrative Expenses:

Total: Dkr. $\begin{array}{rr}340 & 50.00 \\ 6740 & \text { USD } 990.00\end{array}$

We would be truly grateful if Free Europe Citizens' Service of Free Europe Committee, Inc., could grant to the Polish Caritas in Denmark for the above project the sum of Dkr. 6740 - USD 990.00.

With respect to the supplementary schools, we will make available to you $\$$ 500.00 for the following expenditures:

2 teachers salaries (December 1956 to June 1957) $\$ 160.00$

Equipment for 2 schools

100.00

Childrens' library equipment

100.00

Miscellaneous expenses

60.00

Rental of premises at Nykobing

80.00

${ }^{31}$ AGOG, sign. 339, Project Polish Youth Choral and Theatrical Club, pp. 1-3; AAW, sign. 123, pp. 1-2; ARN, Msgr Gogoliński, pp. 17. 
You will note that no rental allowance is made for Copenhagen, since it is our understanding that the Polish Community Center may be used for this purpose.

In regard to the youth recreation center activities, we are prepared to assist to the extend of $\$ 1400.00$ for the following expenditures:

Teachers and sports instructors for three

Centers (December 1956 to June 1957)

$\$ 480.00$

Equipment for three centers

300.00

Youth library

150.00

Excursions, contests, parties, etc.

150.00

Rental of premises at Nykobing and Horsens

320.00

No rental allowance has been made for Copenhagen, inasmuch as the Polish Community Center can be used for this purpose. ${ }^{32}$

\section{BIBLIOGRAPHY}

\section{Archival documentation}

Archives Rev. Msgr Aleksander Gogoliński-Elston, War Relief Services-NCWC, Polish Projects in Great Britain, London [AGOG].

Signature: $511-513 ; 314-340$.

Archives Rev. Msgr Roman Nir, Chicago-Częstochowa [ARN].

Signature: 4-18.

Archives of War Relief Services/National Catholic Welfare Conference. Special Collections, Alousius J. Wycislo Papers, Baltimore, Maryland [AAW].

Signature: $101-124$.

Archives Catholic University of America. Department of Archives, Manuscript and Museum Collection: National Catholic Welfare Conference/United States Catholic Conference Collection Descript 1919-1995 [ACUA].

Signature: $501-505$.

\section{THE ACTIVITIES OF THE POLISH CATHOLIC CARITAS IN GREAT BRITAIN, ITALY AND DENMARK 1956-1962}

\section{Summary}

In 1945, Fr. Rafał Gogoliński-Elston made contact between the Archbishop of Kraków, Adam Stefan Sapieha, and the National Catholic Welfare Conference (NCWC) in order to provide charity assistance by the NCWC to Poles in the country, through Caritas in Poland.

${ }^{32}$ AGOG, sign. 340, Polish Caritas in Denmark, pp. 1-2; AAW, sign. 124, pp. 1-3; ACUA, sign. 505; ARN, Msgr Gogoliński, pp. 18. 
In 1946-1948, medicine, clothing, food for \$ 80,000 was sent to Poland from the NCWC warehouses in Great Britain. Six trucks for Caritas were sent to Poland, children's homes were sent blankets, bed linen, kitchen appliances, stationary such as paper, pencils, ink and typewriters.

In 1950-1951, 80 boxes containing medicine and medical equipment worth over $\$ 10,000$ were sent to Poland. In 1952 Fr. Rafał Gogoliński-Elston founded the Polish Catholic Caritas Branch in Great Britain. Polish Caritas in Great Britain in the years 1952-1957 sent to Poland: 4,000 food parceles, CARE for a total amount of $\$ 40,000 ; 6,000$ food packages, from the US Department of Agriculture, worth \$30,000.

In the years 1950-1960, Poland Caritas sent Christmas parcels for Polish priests who where in difficult financial conditions. Every year, over 100 parcels were sent during Christmas. In total over \$ 4,000. Caritas helped children and youth in Polish Catholic schools in Great Britain. Granted scholarship to students. In financed 106 summer camps for 2,650 children.

In November 1956, Fr. Rafał Gogoliński-Elston founded the Branches of the Polish Catholic Caritas in Denmark and Sweden, having abtained funds for these Departments Denmark received finances for: 2 Polish schools for Polish children; 3 Polish community centers; 6 mobile Polish libraries; for youth theater and the activity of a Polish priest, $\$ 4,780$. Sweden has received finances for: 11 Polish Saturday schools, 6 mobile Polish libraries, 1 youth club, all for a total of $\$ 3.890$.

Keywords: Polish Catholic Caritas in Great Britain, Italy and Denmark; charity activities after World War II

\section{DZIAŁALNOŚĆ POLSKIEGO CARITAS KATOLICKIEGO W WIELKIEJ BRYTANII, WŁOSZECH I DANII W LATACH 1956-1962}

\section{Streszczenie}

W 1945 r. ks. Rafał Gogoliński-Elston nawiązał kontakt z arcybiskupem krakowskim księciem Adamem Stefanem Sapiehą i krajową konferencją NCWC w celu niesienia pomocy przez NCWC Polakom w kraju za pośrednictwem Caritas w Polsce. W latach 1946-1948 z magazynów NCWC w Wielkiej Brytanii wysłano do Polski lekarstwa, odzież, żywność o wartości 80000 dolarów. Do Polski wysłano sześć ciężarówek z darami dla Caritasu, domy dziecka otrzymały koce, pościel, sprzęt kuchenny, artykuły piśmiennicze i biurowe, takie jak papier, ołówki, tusz i maszyny do pisania.

W latach 1950-1951 dostarczono do Polski 80 pudeł z lekarstwami i sprzętem medycznym o wartości ponad 10000 dolarów. W 1952 r. ks. R. Gogoliński-Elston założył w Wielkiej Brytanii polski oddział Caritas. W latach 1952-1957 oddział ten wysłał do Polski 4000 paczek żywnościowych CARE za sumę 40000 dolarów, 6000 paczek żywnościowych z Departamentu Rolnictwa USA na kwotę 30000 dolarów.

W latach 1950-1960 polska Caritas wsparła paczkami świątecznymi polskich księży, którzy znaleźli się w trudnych warunkach finansowych. Każdego roku w okresie Bożego Narodzenia wysyłano ponad 100 paczek o łącznej wartości ponad 4000 dolarów. Caritas pomagała dzieciom 
i młodzieży w polskich szkołach katolickich w Wielkiej Brytanii, udzielając także stypendiów uczniom. Sfinansowała 106 obozów letnich dla 2650 dzieci.

W listopadzie 1956 r. ks. Gogoliński-Elston założył oddziały polskiej Caritas w Danii i Szwecji. Dania otrzymała środki finansowe na dwie szkoły dla dzieci polskich, 3 ośrodki polonijne, 6 mobilnych bibliotek polskich, na teatr młodzieżowy, a także na działalność polskiego księdza (łącznie 4780 dolarów). Szwecja otrzymała pieniądze na dofinansowanie jedenastu polskich szkół sobotnich, sześciu obwoźnych bibliotek z polskimi książkami, jednego klubu młodzieżowego (łącznie 3890 dolarów).

Słowa kluczowe: polska Caritas katolicka w Wielkiej Brytanii, Włoszech i Danii; działalność charytatywna po II wojnie światowej 